Огляди літератури, оригінальні дослідження, погляд на проблему, випадок з практики, короткі повідомлення уДК 616.37-002.2:616.379-008.64:616.34-008.67:[616-008.83:577.164.1]

DOI 10.11603/1811-2471.2020.v.i4.11766

\title{
ПОРУШЕННЯ ВМІСТУ ВІТАМІНІВ ГРУПИ В ПРИ ДИСБІОЗІ КИШЕЧНИКА У ХВОРИХ НА ХРОНІЧНИЙ ПАНКРЕАТИТ ТА ЦУКРОВИЙ ДІАБЕТ 2-ГО ТИПУ
}

\author{
๑є. С. Сірчак, В. Є. Барані, З. Й. Фабрі \\ ДВНЗ «Ужгородський національний університет»
}

РЕЗЮМЕ. Дисбіоз кишечника часто виникає при захворюваннях травного тракту, зокрема при хронічному панкреатиті. Клініка ХП із супутнім ДК ускладнюється синдромом порушення травлення, гіпо- й авітамінозом, диспротеїнемією, інтоксикацією.

Мета - визначити особливості забезпечення вітамінами групи В хворих на ХП та цукровий діабет (ЦД) 2-го типу за наявності дисбіозу товстої кишки (ТК).

Матеріал і методи. Обстежено 82 хворих на ХП та ЦД 2-го типу. Усім обстеженим пацієнтам проведено загальноклінічні дослідження, аналіз калу на дисбіоз, а також визначення рівнів вітамінів $\mathrm{B}_{1}, \mathrm{~B}_{6}, \mathrm{~B}_{9}, \mathrm{~B}_{12}$ у сироватці крові.

Результати. Встановлено, що 51,2 \% хворих на ХП та ЦД 2-го типу мають дисбіоз III ступеня. У хворих на ХП та ЦД 2-го типу виявлено зменшення рівня вітамінів $\mathrm{B}_{9}, \mathrm{~B}_{12}$ у 3,9-2,8 раза та вітамінів $\mathrm{B}_{6}, \mathrm{~B}_{1}$ у 2,6-2,0 рази ( $\left.\mathrm{p}<0,01\right)$, порівняно з показником контрольної групи. Встановлено сильну пряму залежність між III ступенем дисбіозу ТК та рівнями всіх вивчених нами вітамінів групи В. Отже, із прогресуванням вираженості дисбіозу ТК у хворих на ХП та ЦД 2-го типу встановлено зменшення рівня вітамінів групи В із мінімальним відхиленням від показників контрольної групи при дисбіозі ТК I ст. та максимальними відхиленнями - при дисбіозі ТК III ст.

Висновки. У всіх хворих на ХП та ЦД 2-го типу встановлено дисбіоз ТК, причому частіше це дисбіоз ІІІ та ІІ ступенів (у 51,2 \% та у 31,7 \% обстежених відповідно). У хворих на ХП та ЦД 2-го типу виявлено зниження рівнів вітамінів $\mathrm{B}_{1}, \mathrm{~B}_{6}, \mathrm{~B}_{9}, \mathrm{~B}_{12}$, що прямо залежать від вираженості дисбіозу ТК у даних пацієнтів.

КЛючОВІ СЛОВА: хронічний панкреатит; цукровий діабет; дисбіоз; вітаміни групи В.

Вступ. Хронічний панкреатит (ХП) належить до найскладніших поліетіологічних і поліморбідних захворювань. Розповсюдженість ХП серед населення різних країн варіює від 0,2 \% до 0,7 \%, а серед хворих гастроентерологічного профілю досягає 6,0-9,0 \% [1]. Сумація та потенціювання несприятливих ефектів чинників ризику та дія етіологічних факторів ХП сприяють зростанню захворюваності на ХП та його перебігу, що прогресує, із порушенням зовнішньосекреторної недостатності підшлункової залози (ПЗ), розвитку мальдигестії, мальабсорбції, трофологічної недостатності хворих із порушенням усіх видів обміну. Проведені дослідження ланок патогенезу ХП за умов ізольованого перебігу та різноманітної коморбідності доводять важливу роль системного запалення, дисбалансу про- та протизапальних цитокінів, чинників протеїназоінгібіторної системи зі зростанням негативного впливу системного протеолізу, порушення оксидантно-антиоксидантного гомеостазу з активацією оксидативного та нітрозитивного стресу на тлі дефіциту природних антиоксидантів та агентів детоксикації, що сприяє розвитку ендогенної інтоксикації, яка зростає на тлі супровідного дисбіозу товстої кишки; гіперглікемії на на тлі формування панкреатогенного цукрового діабету (ЦД) 3 типу, змін ліпідного та білкового спектра крові, дисбалансу білкових та вуглеводно-білкових компонентів [2-4].

Дисбіоз кишечника (ДК) часто виникає при захворюваннях травного тракту, зокрема при ХП.
Клініка ХП із супутнім дисбіозом кишечника ускладнюється посиленням синдрому кишкової диспепсії (метеоризм, бурчання, здуття живота, дискомфорт, відчуття тяжкості і розпирання, нестабільні випорожнення), синдрому порушення травлення (стеаторея, порушення всмоктування жиророзчинних вітамінів D і K, порушення водноелектролітного балансу), астено-вегетативного синдрому, зумовленого гіпо- й авітамінозом, диспротеїнемією, інтоксикацією $[5,6]$. Отже, дослідження вітамінного забезпечення організму при дисбіозі кишечника у хворих на ХП, особливо при його поєднанні з ЦД 2-го типу, є актуальним у хворих із коморбідними станами.

Мета - визначити особливості забезпечення вітамінами групи В хворих на хронічний панкреатит та цукровий діабет 2-го типу за наявності дисбіозу товстої кишки (ТК).

Наукове дослідження $\epsilon$ фрагметном держбюджетної теми кафедри хірургічних хвороб та кафедри пропедевтики внутрішніх хвороб медичного факультету ДВНЗ «УжНУ» № 851 «Механізми формування ускладнень при захворюваннях печінки та підшлункової залози, методи їх лікування та профілактики", номер державної реєстрації: 0115U001103), а також наукової теми кафедри пропедевтики внутрішніх хвороб «Поліморбідна патологія при захворюваннях органів травлення, особливості патогенезу, можливості корекції (номер державної реєстрації 0118U004365). 
Огляди літератури, оригінальні дослідження, погляд на проблему, випадок з практики, короткі повідомлення

Матеріал і методи дослідження. Під нашим спостереженням перебували 82 хворих на ХП та ЦД 2-го типу, які отримували стаціонарне лікування в ендокринологічному та гастроентерологічному відділеннях КНП «ЗОКЛ імені А. Новака» 3ОД, та хворі, які перебували на амбулаторнодиспансерному спостереженні у дільничного сімейного лікаря за місцем проживання.

Серед обстежених чоловіків було 49 (59,8 \%), жінок - 33 (40,2 \%). Середній вік становив $(49,7 \pm$ $5,3)$ років. У контрольну групу ввійшло 20 практично здорових осіб (11 чоловіків (55,0\%), 9 жінок $(45,0 \%)$. Середній вік складав $(45,2 \pm 5,1)$ років.

Усі дослідження виконували за згодою паці$\epsilon$ нтів, а методика їх проведення відповідала Гельсінській декларації з прав людини 1975 р. та її перегляду 1983 р., Конвенції Ради Європи про права людини і біомедицину та законодавству України.

Усім обстеженим пацієнтам проведено загальноклінічні, антропометричні, інструментальні та лабораторні дослідження. Для верифікації діагнозу звертали увагу на характер скарг, анамнез захворювання. Усім пацієнтам виконано ультразвукове дослідження органів черевної порожнини за загальноприйнятою методикою. Проведено стандартні загальніта біохімічні дослідження сироватки крові з акцентом на показники вуглеводного обміну (глюкози, інсуліну, глікозильованого гемоглобіну (НbA1c, \%), тесту на порушення толерантності до глюкози).

Усім обстеженим хворим у сироватці крові визначали забезпечення вітамінами групи В, а саме: вітаміном $\mathrm{B}_{1}$ (тіамін) та вітаміном $\mathrm{B}_{6}$ (піридоксин) - за допомогою високоефективної рідинної хроматографії (HPLC-System 1100, Aqilent with fluorescence detection) із використанням тестсистем (Recipe complet Kit, Німеччина); вітаміном $\mathrm{B}_{9}$ (фолієва кислота) - за допомогою імунохімічного методу з електрохемілюмінесцентною детекцією (ECLIA - Cobas 6000), використовуючи тест-системи Roche Diagnostics (Швейцарія), а також вітаміну $\mathrm{B}_{12}$ (ціанокобаламін - голотранскобаламін) - за допомогою імунохімічної хемілюмінесцентної детекції (CLIA - Architect), використовуючи тест-системи Abbot Diagnostics (США).

Дослідження якісного і кількісного складу мікрофлори товстої кишки (МТК) проводили методом посіву десятикратних розведень $\left(10^{-1}-10^{-9}\right)$ фекалій на стандартний набір селективних і диференційно-діагностичних поживних середовищ для виділення аеробних і анаеробних мікроорганізмів. Ступінь дисбіозу товстої кишки оцінювали за класифікацією Куваєвої І. Б., Ладодо К. С. (1991р.).

Діагноз ХП встановлювали відповідно до марсельсько-римських критеріїв (1989р.) з доповненнями Я. С. Циммермана (1995 р.) та уточнення- ми MKX-10. Для вивчення зовнішньосекреторної функції (ЗСН) ПЗ проводили копрологічне дослідження, визначали рівні амілази сироватки крові та фекальної еластази-1, а також використовували ${ }^{13} \mathrm{C}-$ змішаний тригліцеридний $\left({ }^{13} \mathrm{C}-3 \mathrm{~T}\right.$ ДТ) та ${ }^{13} \mathrm{C}$-амі-

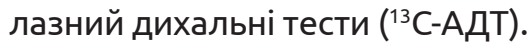

Надання медичної допомоги обстеженим хворим на ЦД проводили згідно з клінічними протоколами МОЗ України та локальних протоколів. Діагноз ЦД 2-го типу встановлений згідно з рекомендаціями IDF (2005р.), а також із урахуванням критеріїв уніфікованого клінічного протоколу (наказ МОЗ України від 21.12.2012 № 1118) [8, 9]. Ступінь тяжкості ЦД 2-го типу оцінювали за рівнем HbA1с (норма - до 6,0 \%).

Аналіз і обробку результатів обстеження хворих здійснювали за допомогою комп'ютерної програми STATISTICA 10.0 (фірми StatSoft Inc, USA) 3 використанням параметричних та непараметричних методів оцінки отриманих результатів.

Результати й обговорення. У всіх обстежених хворих діагностований хронічний панкреатит за даними результатів клініко-лабораторних та інструментальних методів обстеження, що проявлявся порушенням зовнішньосекреторної функції підшлункової залози за даними копрологічного дослідження, змінами рівня амілази у сироватці

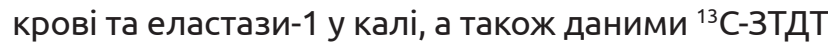

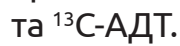

У всіх обстежених нами пацієнтів також діагностовано ЦД 2-го типу, переважно легкого та середнього ступенів тяжкості, що характеризувався відсутністю гіпоглікемічних реакцій, рівенем глюкози в крові натще до 8,5 ммоль/л, після їди - до 10 ммоль/л, показник НbA1с не перевищував 7 \%.

Оцінка результатів мікробіологічного дослідження фекалій у обстежених хворих на ХП та ЦД 2-го типу вказує на виражені зміни в кількісному і якісному складі МТК. У всіх хворих визначали зниження рівня представників анаеробної флори: біфідобактерій - нижче $10^{7}$, а також лактобактерій нижче $10^{6}$, що супроводжувалось підвищенням кількості представників патогенної мікрофлори у ТК,

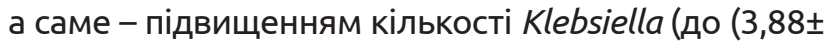
$0,24)$ lg КОЕ/г), Proteus (до $(2,75 \pm 0,17)$ lg КОЕ/г), Clostridium (до $(5,34 \pm 0,11) \mathrm{lg}$ KOE/г), патогенних Staphylococcus (до $(4,90 \pm 0,14)$ lg KOE/г), а також грибів роду Candida (до $(4,14 \pm 0,18) \mathrm{lg}$ KOE/г). Отже, аналіз отриманих результатів порушень мікробного складу у товстій кишці у хворих на ХП та ЦД 2-го типу підтверджує дисбіотичні зміни у всіх 82 обстежених, які перебували під нашим спостереженням (рис. 1).

Аналіз ступеня тяжкості дисбіотичних змін вказує на те, що переважна більшість $(51,2$ \%) хворих на ХП та ЦД 2-го типу мають дисбіоз III ступеня. Дисбіоз II ступеня встановлено у 31,7 \% пацієн- 
Огляди літератури, оригінальні дослідження, погляд на проблему, випадок з практики, короткі повідомлення

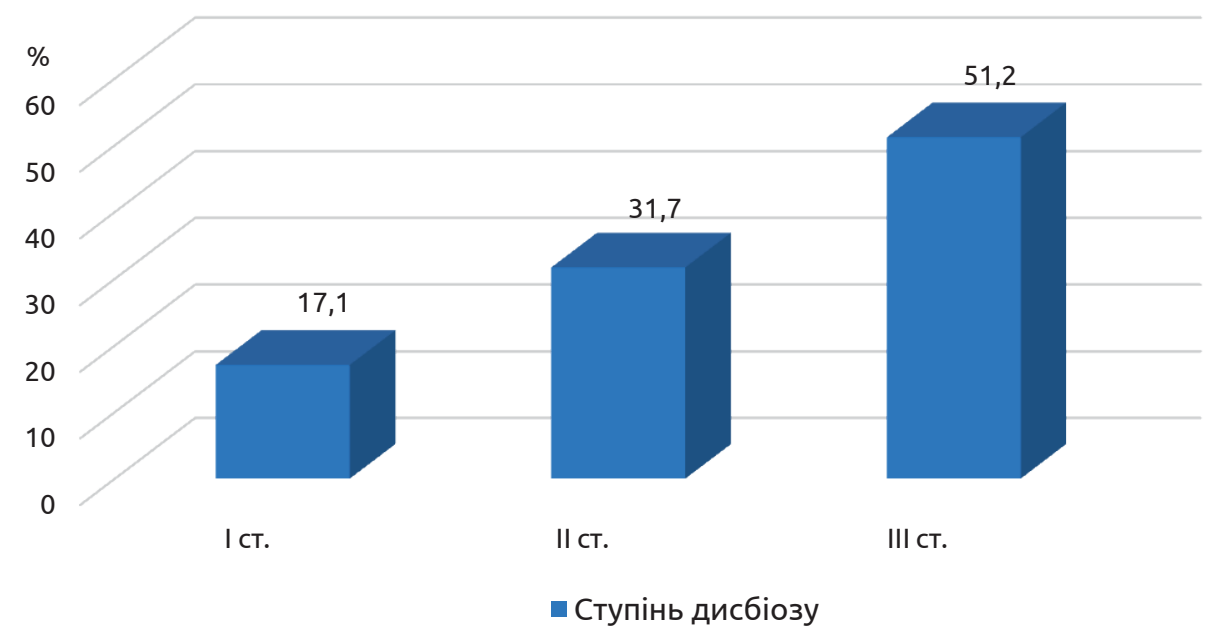

Рис. 1. Розподіл обстежених хворих на хронічний панкреатит та цукровий діабет 2-го типу за ступенем тяжкості дисбіозу товстої кишки.

тів, і лише у 17,1 \% пацієнтів виявлено дисбіоз І ступеня. У жодного обстежуваного хворого не діагностовано дисбіоз IV ступеня.
Усім хворим на ХП та ЦД 2-го типу проведено визначення забезпечення вітамінами групи $\mathrm{B}$, що представлено у таблиці 1.

Таблиця 1. Рівень вітамінів групи В у хворих на хронічний панкреатит та цукровий діабет 2-го типу та обстежених контрольної групи

\begin{tabular}{|c|c|c|c|}
\hline \multirow[b]{2}{*}{ Показник } & \multirow[b]{2}{*}{ Референтні значення } & \multicolumn{2}{|c|}{ Обстежені } \\
\hline & & $\begin{array}{c}\text { контрольна група } \\
(\mathrm{n}=20)\end{array}$ & $\begin{array}{c}\text { хворі на ХП та ЦД } 2 \text { типу } \\
(n=82)\end{array}$ \\
\hline Вітамін В $_{1}$ мкг/л & Більше 49 & $73,2 \pm 2,4$ & $37,4 \pm 3,1^{*}$ \\
\hline Вітамін В ${ }_{6}$ мкг/л & $8,7-27,2$ & $18,5 \pm 1,7$ & $7,1 \pm 1,9 *$ \\
\hline Вітамін B $_{9}$ нг/мл & $4,6-18,7$ & $14,5 \pm 0,9$ & $3,7 \pm 0,6^{*}$ \\
\hline Вітамін $\mathrm{B}_{12}$, пг/мл & $197,0-771,0$ & $524,1 \pm 9,5$ & $189,9 \pm 10,2 *$ \\
\hline
\end{tabular}

Примітка. Відмінності між показниками в обстежених контрольної групи та обстежених пацієнтів достовірні: * - p <0,01.

Встановлено суттєве зниження рівня всіх досліджених нами вітамінів групи В у хворих на ХП та ЦД 2-го типу. При цьому найбільш виражене зниження виявлено за показниками вітамінів $\mathrm{B}_{9}$ та $B_{12}$ - їх рівень був зменшеним у 3,9 та у 2,8 раза, порівняно з такими показниками обстежених контрольної групи $(p<0,01)$. Показники вітамінів
$\mathrm{B}_{6}$ та $\mathrm{B}_{1}$ також були нижчими, порівняно із рівнями у осіб контрольної групи - у 2,6 та у 2,0 рази відповідно $(p<0,01)$.

Усім хворим на ХП та ЦД 2-го типу проведено визначення змін рівнів вітамінів групи В залежно від вираження дисбіотичних змін товстої кишки (табл. 2).

Таблиця 2. Зміни рівнів вітамінів групи В у хворих на хронічний панкреатит та цукровий діабет 2-го типу залежно від ступеня вираження дисбіозу товстої кишки

\begin{tabular}{|l|c|c|c|c|}
\hline \multirow{2}{*}{\multicolumn{1}{|c|}{ Показник }} & \multirow{2}{*}{$\begin{array}{c}\text { Контрольна група } \\
(\mathrm{n}=20)\end{array}$} & \multicolumn{3}{|c|}{ Розподіл хворих залежно від ступеня вираження дисбіозу } \\
\cline { 3 - 5 } & & І $(\mathrm{n}=82)$
\end{tabular}

Примітка. Відмінності між показниками в осіб контрольної групи та обстежених пацієнтів достовірні: * $-p<0,05, * *-p<0,01$; *** - p<0,001; відмінності між показниками у хворих з дисбіозом I ст. та II-III ст. достовірні: + - p<0,05. 
Огляди літератури, оригінальні дослідження, погляд на проблему, випадок з практики, короткі повідомлення

Як видно із наведених вище результатів, із прогресуванням вираження дисбіозу ТК у хворих на ХП та ЦД 2-го типу зменшуються рівні вітамінів групи Віз мінімальними відхиленнями від показників контрольної групи при дисбіозі ТК I ст., та максимальними відхиленнями - при дисбіозі ТК III ст.
Проведений кореляційний аналіз встановив сильну пряму залежність між III ступенем дисбіозу ТК та рівнями всіх вивчених нами вітамінів групи В. Аналіз даних вказує, що найбільш виражено у хворих на ХП та ЦД 2-го типу знижувався рівень вітаміну $\mathrm{B}_{12}$ (табл. 3).

Таблиця 3. Зіставлення ступенів дисбіозу товстої кишки та показників вітамінів групи В у хворих на хронічний панкреатит та цукровий діабет 2-го типу

\begin{tabular}{|l|c|c|c|}
\hline \multirow{2}{*}{ Показник крові } & \multicolumn{3}{|c|}{ Ступінь дисбіозу ТК у хворих на ХП та ЦД 2-го типу } \\
\cline { 2 - 4 } & І ступінь & II ступінь & III ступінь \\
\hline Вітамін $\mathrm{B}_{1}$ & - & $\mathrm{r}=0,64 ; \mathrm{p}<0,05$ & $\mathrm{r}=0,92 ; \mathrm{p}<0,01$ \\
\hline Вітамін $\mathrm{B}_{6}$ & $\mathrm{r}=-0,48 ; \mathrm{p}<0,05$ & $\mathrm{r}=0,58 ; \mathrm{p}<0,05$ & $\mathrm{r}=0,90 ; \mathrm{p}<0,01$ \\
\hline Вітамін $\mathrm{B}_{9}$ & $\mathrm{r}=0,56 ; \mathrm{p}<0,05$ & $\mathrm{r}=0,62 ; \mathrm{p}<0,05$ & $\mathrm{r}=0,94 ; \mathrm{p}<0,01$ \\
\hline Вітамін $\mathrm{B}_{12}$ & $\mathrm{r}=0,82 ; \mathrm{p}<0,01$ & $\mathrm{r}=0,86 ; \mathrm{p}<0,01$ & $\mathrm{r}=0,98 ; \mathrm{p}<0,01$ \\
\hline
\end{tabular}

Отже, у хворих з порушенням інкреторної та екскреторної функцій ПЗ визначаються зміни мікробного пейзажу ТК - це дисбіоз переважно III ступеня. Дисбіотичні зміни у обстежених пацієнтів супроводжуються зменшенням рівня в організмі таких водорозчинних вітамінів групи В, як ціанокобаламін, фолієва кислота, піридоксин, тіамін. Порушення зовнішньосекреторної функції ПЗ, що супроводжується синдромом мальабсорбції, а також зміна профілю бактеріального складу ТВ призводять до порушення бар'єрної функції кишечника, що й лежить в основі виникнення/прогресування зниження вітамінного забезпечення у хворих на ХП та ЦД 2-го типу.

\section{ЛITEPATУРA}

1. Бабінець Л. С. Можливості комплексної реабілітації хворих на хронічний панкреатит на етапі первинної медичної допомоги (огляд літератури) / Л. С. Бабінець, М. В. Палихата, Г. М. Сасик // Вестник Клуба Панкреатологов. - 2018. - № 2. - С. 4-11.

2. Клінічна ефективність препарату Антраль® у хворих на хронічний панкреатит / О. С. Хухліна, І.В. Дудка, Т. В. Дудка, В. С. Смандич // Здоров'я України. 2020. - № 3. - С. 17.

3. Протеолітичний дисбаланс як фактор розвитку хронічного панкреатиту окремо та за наявності цукрового діабету 1 типу / Н. Г. Ракша, Т. І. Галенова, Т. Б. Вовк [та ін.] // Вісник проблем біології і медицини. - 2019. № 3 (152). - С. 186-191.

4. Христич Т. М. Етіологічні фактори, що формують хронічний панкреатит / Т. М. Христич, Д. О. Гонцарюк // Здобутки клінічної та експериментальної медицини. 2018. - № 3. - С. 20-27.
Висновки. 1. У всіх хворих на ХП та ЦД 2-го типу встановлено дисбіоз ТК, причому частіше це дисбіоз III та ІІ ступенів (у 51,2 \% та у 31,7 \% обстежених відповідно).

2. У хворих на ХП та ЦД 2-го типу виявлено зниження рівнів вітамінів $\mathrm{B}_{1}, \mathrm{~B}_{6}, \mathrm{~B}_{9}, \mathrm{~B}_{12}$, що прямо залежить від вираженості дисбіозу ТК у даних пацієнтів.

Перспективи подальших досліджень. Подальше дослідження особливостей вітамінного забезпечення у хворих на ХП та ЦД 2-го типу для розробки ефективних методів їх корекції.

5. Коцаба Ю. Я. Актуальні аспекти застосування пробіотиків при дисбіозі товстої кишки / Ю. Я. Коцаба, Л. С. Бабінець // Сімейна медицина. - 2018. - № 4 (78). С. $85-87$.

6. Ларин А. С. Патогенетическая роль кишечного дисбиоза в развитии ожирения, инсулинорезистентности и сахарного диабета 2 типа / А. С. Ларин, С. М. Ткач // Здоров'я України. Тематичний номер. Гастроентерологія. Гепатологія. Колопроктологія. - 2016. - № 2 (40). - С. 20-21.

7. WHO: Global Database on Body Mass Index. Available at: http://apps.who.int/bmi/index.jsp?introPage=intro_3.html

8. Уніфікований клінічний протокол первинної та вторинної (спеціалізованої) медичної допомоги: Цукровий діабет 2 типу // Наказ Міністерства охорони здоров' я України від 21 грудня 2012 р. № 1118. - 118 с.

9. Цукровий діабет 2 типу / М.В.Гульчій, Л. Ф. Матюха, В. З. Нетяженко [та ін.] // Адаптована клінічна настанова, заснована на доказах. - Київ, 2012. - 343 с. 
Огляди літератури, оригінальні дослідження, погляд на проблему, випадок з практики, короткі повідомлення REFERENCES

1. Babinets, L.S., Palykhata, M.V., \& Sasyk, G.M. (2018). Mozhlyvosti kompleksnoi reabilitatsii khvorykh na khronichnyi pankreatyt na etapi pervynnoi medychnoi dopomohy (ohliad literatury) [Possibilities of complex rehabilitation of patients with chronic pancreatitis at the stage of primary care (literature review)]. Vestnyk Kluba Pankreatolohov - Pancreatology Club Bulletin, 2, 4-11 [in Ukrainian].

2. Huhlina, O.S., Dudka, I.V., Dudka, T.V., \& Smandich, V.S. (2020). Klinichna efektyvnist preparatu Antral@ u khvorykh na khronichnyw pankreatyt [Clinical efficacy of Antral $\circledast$ in patients with chronic pancreatitis]. Zdorovia Ukrainy - Health of Ukraine, 3, 17 [in Ukrainian].

3. Raksha, N.G., Halenova, T.I., Vovk, T.B., Sukhodolia, S.A., Beregova, T.V., \& Ostapchenko, L.I. (2019). Proteolitychnyi dysbalans yak faktor rozvytku khronichnoho pankreatytu okremo ta za naiavnosti tsukrovoho diabetu 1 typu [Proteolitic imbalance as a key factor of the development of chronic pancreatitis with and without type 1 diabetes mellitus]. Visnнk problem biolohii i medytsyny Bulletin of Problems of Biology and Medicine, 3 (152), 186191 [in Ukrainian].

4. Hristich, T.M., \& Hontsariuk, D.O. (2018). Etiolohichni faktory, shcho formuiut khronichnyi pankreatyt [Etiological factors which from the chronical pancreatitis]. Zdobutky klinichnoi i eksperymentalnoi medytsyny - Achievements of Clinical and Experimental Medicine, 3, 20-27 [in Ukrainian].

5. Kotsaba, Yu.Ya, \& Babinets, L.S. (2018). Aktualni aspekty zastosuvannia probiotykiv pry dysbiozi tovstoi kysh- ky [Topical aspects of the use of probiotics in colonic dysbiosis]. Simeina medytsyna - Family Medicine, 4 (78), 85-87 [in Ukrainian].

6. Larin, A.S., \& Tkach, S.M. (2016). Phatogeneticheskaya rol kishechnogo disbioza v razvitii ozhireniya, insulinorezistentnosti i sakharnogo diabeta 2 tipa [Pathogenetic role of intestinal dysbiosis in the development of obesity, insulin resistance and type 2 diabetes]. Zdorovia Ukrainy. Tematychnyi nomer. Hastroenterolohiia. Hepatolohiia. Koloproktolohiia - Health of Ukraine. Thematic Issue. Gastroenterology. Hepatology. Coloproctology, 2 (40), 2021 [in Russian].

7. WHO: Global Database on Body Mass Index. Retrieved from:http://apps.who.int/bmi/index.jsp?introPage=intro_3. html.

8. (2012). Ministerstvo okhorony zdorovia Ukrainy. Unifikovanyi klinichnyi protokol pervynnoi ta vtorynnoi (spetsializovanoi) medychnoi dopomohy: Tsukrovyi diabet 2 typu. Nakaz Ministerstva okhorony zdorovia Ukrainy [Ministry of Health of Ukraine. Unified clinical protocol for primary and secondary (specialized) care: Type 2 Diabetes Mellitus]. Order of the Ministry of Health of Ukraine No. 1118 [in Ukrainian].

9. Hulchii, M.V., Matiukha, L.F., Netiazhenko, V.Z., Sirenko, Yu.M., Vlasenko, M.V., Vlasenko, I.A., ..., \& Chaharna, N.S. (2012). Tsukrovyi diabet 2 typu. Adaptovana klinichna nastanova, zasnovana na dokazakh [Type 2 Diabetes Mellitus. Adapted clinical guideline based on evidence]. Kyiv [in Ukrainian].

\section{НАРУШЕНИЕ СОДЕРЖАНИЯ ВИТАМИНОВ ГРУППЫ В ПРИ ДИСБИОЗЕ КИШЕЧНИКА У БОЛЬНЫХ ХРОНИЧЕСКИМ ПАНКРЕАТИТОМ И САХАРНЫМ ДИАБЕТОМ 2-ГО ТИПА ๑Е. С. Сирчак, В. Е. Барани, З. Й. Фабри

\author{
ГВУЗ «Ужгородский национальный университет»
}

PЕзЮМЕ. Дисбиоз кишечника часто возникает при заболеваниях пищеварительного тракта, в частности при хроническом панкреатите. Клиника ХП с сопутствующим ДК осложняется синдромом нарушения пищеварения, гипо- и авитаминозом, диспротеинемией, интоксикацией.

Цель исследования - определить особенности обеспечения витаминами группы В больных ХП и сахарным диабетом (СД) 2-го типа при наличии дисбиоза толстой кишки (ТК).

Материал и методы. Обследовано 82 больных ХП и СД 2-го типа. Всем обследованным пациентам проведены общеклинические исследования, анализ кала на дисбиоз, а также определение уровня витаминов $\mathrm{B}_{1}, \mathrm{~B}_{6}, \mathrm{~B}_{9}, \mathrm{~B}_{12}$ в сыворотке крови.

Результаты. Установлено, что 51,2 \% больных ХП и СД 2-го типа имеют дисбиоз ІІІ степени. У больных ХП и СД 2-го типа выявлено снижение уровня витаминов $\mathrm{B}_{9}, \mathrm{~B}_{12}$ в 3,9-2,8 раза и витаминов B , $_{1}$ в 2,6-2,0 раза ( $<<0,01$ ), по сравнению с показателем контрольной группы. Установлено сильную прямую зависимость между III ст. дисбиоза ТК и уровнями всех обследованных нами витаминов группы В. При прогрессировании выраженности дисбиоза ТК у больных ХП и СД 2-го типа установлено снижение уровня витаминов группы В с минимальным отклонением от показателей контрольной группы при дисбиозе ТК I ст. и максимальным отклонением - при дисбиозе TK III CT.

Выводы. У всех больных ХП и СД 2-го типа установлен дисбиоз ТК, причем, чаще это дисбиоз III и II степеней (у 51,2 \% и 31,7 \% обследованных соответственно). У больных ХП и СД 2-го типа выявлено снижение уровней витаминов $\mathrm{B}_{1}, \mathrm{~B}_{6}, \mathrm{~B}_{9}, \mathrm{~B}_{12}$ которое прямо зависит от выраженности дисбиоза ТК у данных пациентов.

КЛЮЧЕВЫЕ СЛОВА: хронический панкреатит; сахарный диабет; дисбиоз; витамины группы В. 
Огляди літератури, оригінальні дослідження, погляд на проблему, випадок з практики, короткі повідомлення

DISORDERS OF B VITAMINS IN INTESTINAL DYSBIOSIS IN PATIENTS WITH CHRONIC PANCREATITIS AND TYPE 2 DIABETES

○Ye. S. Sirchak, V. Ye. Barani, Z. Yo. Fabri

\section{Uzhhorod National University}

SUMMARY. Intestinal dysbiosis (DB) often occurs in diseases of the digestive tract, in particular in chronic pancreatitis (CP). Clinical manifestation of CP combined with diabetes mellitus (DM) is complicated by indigestion syndrome, hypo- and avitaminosis, dysproteinemia, intoxication.

The aim of the study - to determine the features of B vitamins in patients with CP and DM type 2 in the presence of colon dysbiosis (CDB).

Material and Methods. 82 patients with CP and DM type 2 were examined. All examined patients underwent general clinical studies, feces for dysbiosis, as well as determining the level of vitamin B1, B6, B9, B12 in the blood serum.

Results and Discussion. It was found that $51.2 \%$ of patients with CP and DM have dysbiosis stage III. In patients with CP and DM type 2 were found a decrease the level of vitamin B9, B12 by 3.9-2.8 times and vitamin B6, B1 by 2.6 - 2.0 times $(p<0.01)$ compared with the control group. A strong direct relationship was found between the CDB stage III and the levels of all B vitamins, examined by us. Thus, with the progression of the severity of CDB in patients with CP and DM type 2, determined a decrease of the level of $B$ vitamins with minimal deviation from the control group in CDB of stage I and maximum deviations - in CDB stage III.

Conclusions. All patients with CP and DM type 2 were diagnosed a CDB, and more often it was stage III and II ( $51.2 \%$ and $31.7 \%$ of those examined, respectively). In patients with CP and DM type 2 were found a decrease in the levels of vitamins B1, B6, B9, B12, which directly depend on the severity of CDB in these patients.

KEY WORDS: chronic pancreatitis; diabetes mellitus; dysbiosis; B vitamins. 